\title{
The xenarthrans of Honduras: new records, main threats, and comments on their conservation status
}

\author{
Manfredo A. Turcios-Casco ${ }^{\mathrm{A}, 1}$, Hefer D. Ávila-Palma ${ }^{\mathrm{B}}$, Marcio Martínez $^{\mathrm{C}}$, \\ Eduardo J. Trejo-Ordoñez ${ }^{\mathrm{B}}$, David E. Meza-Flores ${ }^{\mathrm{D}}$, Franklin Castañeda ${ }^{\mathrm{E}}$, \\ Travis King ${ }^{\mathrm{F}}$, DANiEl ThORnton ${ }^{\mathrm{F}}$ \& MARIElla Superina ${ }^{\mathrm{G}}$
}

A Departamento de Vida Silvestre, Instituto Nacional de Conservación y Desarrollo Forestal, Áreas Protegidas y Vida Silvestre (ICF), Brisas de Olancho, Francisco Morazán, Honduras

${ }^{B}$ Escuela de Biología, Universidad Nacional Autónoma de Honduras (UNAH), Boulevard Suyapa, Tegucigalpa, Honduras

‘ Región Biosfera del Río Plátano, Instituto Nacional de Conservación y Desarrollo Forestal, Áreas Protegidas y Vida Silvestre (ICF), Marañones, Olancho, Honduras

${ }^{\mathrm{D}}$ Asociación de Investigación para el Desarrollo Ecológico y Socioeconómico (ASIDE), Barrio Las Delicias, El Progreso, Yoro, Honduras

E Panthera, Col. Los Robles, Bloque L, 3415, Tegucigalpa, Honduras

FWashington State University, School of the Environment, 1230 Webster Hall, Pullman, WA 99163, USA

${ }^{\complement}$ Laboratorio de Medicina y Endocrinología de la Fauna Silvestre, IMBECU - CCT CONICET Mendoza - UNCuyo, Mendoza, Argentina

${ }^{1}$ Corresponding author. E-mail: manturcios21@gmail.com

\begin{abstract}
The Xenarthra are one of the least studied mammalian groups in Honduras. Their ecology, natural history, and distribution in the country are poorly known. Here we compile and discuss, for the first time, the available information about the seven species of Xenarthra that occur in Honduras. We also present new distribution records and comment on their main threats. The lack of specific scientific studies, poaching, illegal traffic, cultural beliefs, and deforestation are among the main threats to xenarthrans in Honduras.
\end{abstract}

Keywords: anteaters, armadillos, Central America, sloths, Xenarthra

\begin{abstract}
Los xenartros de Honduras: nuevos registros, principales amenazas y comentarios sobre su estado de conservación

Resumen Xenarthra es uno de los grupos de mamíferos menos estudiados en Honduras, y de los que menos se sabe sobre su ecología, historia natural y distribución en el país. Aquí recopilamos y discutimos, por primera vez, la información disponible de cada una de las siete especies de Xenarthra que ocurren en Honduras. También presentamos nuevos registros de distribución y comentamos sobre las principales amenazas. La falta de estudios científicos, la cacería y el tráfico ilegal, creencias culturales y la deforestación están entre algunas de las principales amenazas para los xenartros en Honduras.
\end{abstract}

Palabras clave: armadillos, Centroamérica, hormigueros, perezosos, Xenarthra

\section{BRIEF SUMMARY OF MAMMALOGY IN HONDURAS: HOW MANY XENARTHRA SPECIES DO WE HAVE?}

Honduras is the second largest country of the Central American isthmus (Hernández Oré et al., 2016) (FIG. 1). Its territory includes an area of $112,492 \mathrm{~km}^{2}$ (excluding the marine territory), and it has a population of some 9.02 million inhabitants (INE, 2018). According to Duarte et al. (2014), 48\% of the national territory of Honduras is covered by forests and $27 \%$ are protected areas. Even though it is a biodiverse country, many ecosystems remain poorly studied (e.g., dry forests, mangroves). 
The baseline for mammalian research in Honduras was established by Goodwin (1942) in his seminal work The mammals of Honduras. Goodwin described 123 species of mammals within Honduras based on 2,213 specimens that had been collected primarily in the western and central region of the country by Cecil F. Underwood. Most species were based on a small number of scattered records. The lack of solid records from the entire extent of the country is still true; most of the available information on the mammals of Honduras, excluding large mammals, is based on technical reports, incomplete inventories, or specimens in personal collections that are not easily accessible. The exact number of mammal species in Honduras is uncertain, as research has mainly focused on certain taxonomic groups. For example, recent studies revealed that Chiroptera alone includes 113 species (Turcios-Casco et al., 2020), a number that corresponds to $92.3 \%$ of all mammals known for Honduras by 1942. Most national and international universities, governmental, and non-governmental entities have concentrated their research efforts on large mammals, such as Cervidae, Felidae, Tapiridae, and Tayassuidae. However, taxa such as insectivores, marsupials, rodents, and xenarthrans remain poorly studied. Except for bats, most of the information on small and medium-sized mammals is based on sporadic records obtained while studying large mammals.

Xenarthrans remain particularly understudied in Honduras. Goodwin (1942) mentioned five species: three anteaters (Cyclopes didactylus-now Cy. dorsalis, Miranda et al. (2018)-Myrmecophaga tridactyla, and Tamandua mexicana) and two armadillos (Cabassous centralis and Dasypus novemcinctus). Interestingly, Goodwin (1942) presented convincing evidence for the occurrence of only two

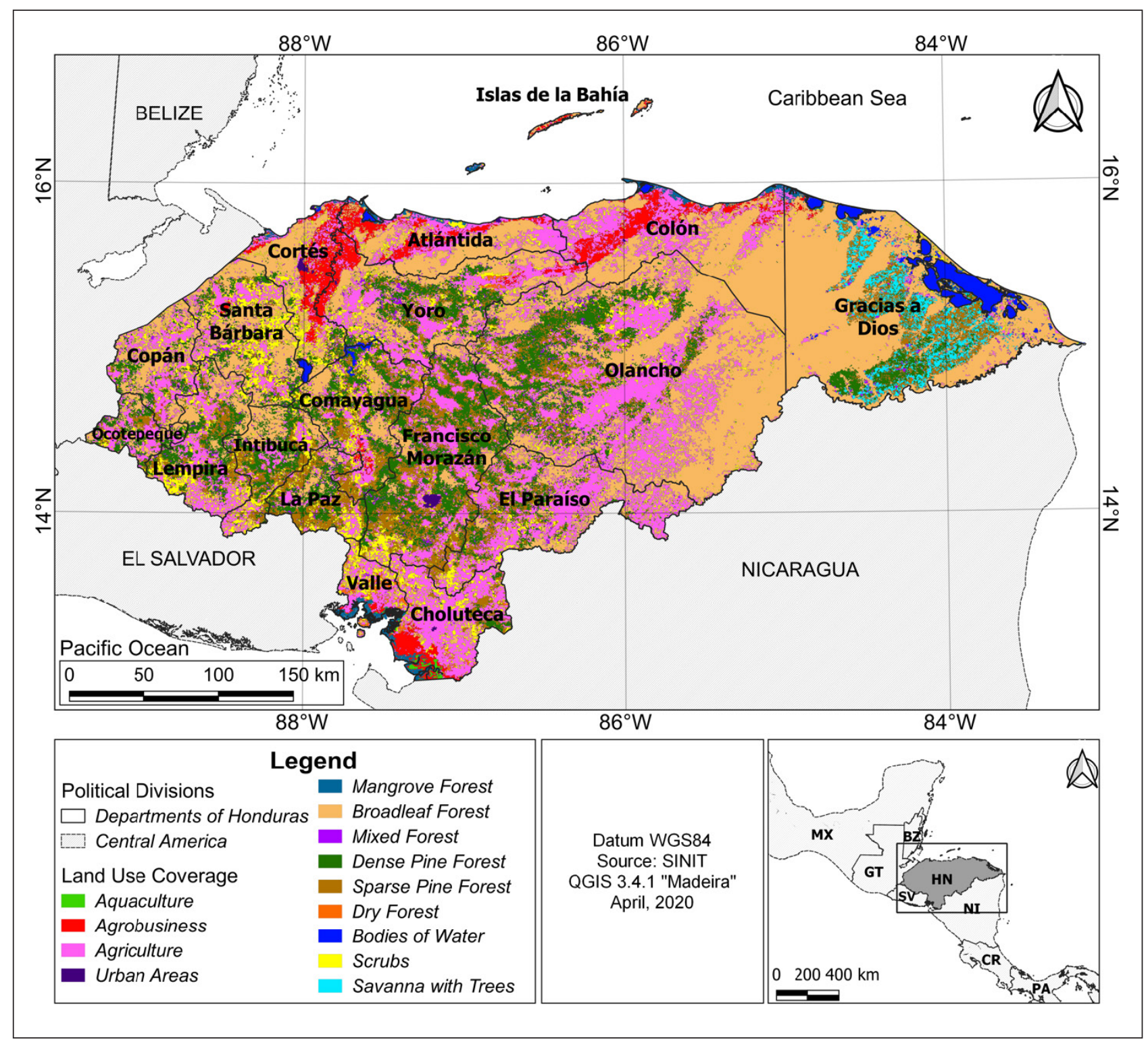

FIGURE 1. Geographical location and land use coverage of Honduras. 
TABLE 1. Common names for Xenarthra in Honduras, in Spanish and different indigenous languages. Source: Jones (1965), Marineros \& Martínez (1998), SDGEPIAH (2015), and this work.

\begin{tabular}{|c|c|c|c|c|c|c|}
\hline Species & Spanish & Lenca & Miskitu & Pesh & Tawahka & Garífuna \\
\hline Bradypus variegatus & $\begin{array}{l}\text { perezoso de tres dedos, } \\
\text { perico lerdo, camaleón, } \\
\text { pereza }\end{array}$ & & siwaiku & & & \\
\hline Choloepus hoffmanni & $\begin{array}{l}\text { perezoso de dos dedos, } \\
\text { pereza, camaleón, } \\
\text { perico lerdo }\end{array}$ & & siwaiku & & um & \\
\hline Cyclopes dorsalis & $\begin{array}{l}\text { serafín, perezocito, osito } \\
\text { del platanar, ceibita }\end{array}$ & & likur & & wísurh & \\
\hline Myrmecophaga tridactyla & $\begin{array}{c}\text { oso hormiguero, oso } \\
\text { caballo, hormiguero } \\
\text { gigante }\end{array}$ & sisitan & wingku tara & corauya & $\begin{array}{l}\text { dánka- } \\
\text { takálvas }\end{array}$ & $\begin{array}{l}\text { liwa, oso } \\
\text { gaballu }\end{array}$ \\
\hline Tamandua mexicana & $\begin{array}{l}\text { tamandua, oso melero, } \\
\text { oso hormiguero } \\
\text { pequeño, perico ligero, } \\
\text { oso de colmena }\end{array}$ & $\begin{array}{l}\text { zegüe, zapu, } \\
\text { corca }\end{array}$ & wingku & & kárkin & \\
\hline Cabassous centralis & $\begin{array}{c}\text { tumbo, tumbo armado, } \\
\text { pitero de uña, cusuco } \\
\text { lechoso }\end{array}$ & & & patáwã & tákan tákan & \\
\hline Dasypus novemcinctus & $\begin{array}{l}\text { cusuco, cusuco de } \\
\text { nueve bandas, pitero }\end{array}$ & yagu & $\begin{array}{l}\text { taiirraa, tahira, } \\
\text { ukmiktaira }\end{array}$ & $\begin{array}{l}\text { pantan waá, } \\
\text { patáwã }\end{array}$ & úmika & gasigamu \\
\hline
\end{tabular}

xenarthrans, D. novemcinctus and T. mexicana, while he expected the other anteater and armadillo species, but not sloths, to occur in the country. At that time, there were only anecdotal records of Bradypus variegatus and Choloepus hoffmanni in Honduras, which were officially recorded more than 50 years later (McCarthy et al., 1999), as discussed below. In addition, there is evidence of extinct xenarthrans in Honduras (Jackson \& Fernandez, 2005; Lucas, 2008; Ferreira \& Feijó Ramos, 2011; Zúniga et al., 2019).

Hall (1981) considered six xenarthran species as occurring in Honduras: B. variegatus, T. mexicana, M. tridactyla, Cy. dorsalis, D. novemcinctus, and C. centralis, but no specific records were given for the last two species. Marineros \& Martínez (1998) provided unconfirmed (and, in most cases, imprecise) localities for most of the mammalian species in the country, including all xenarthrans. No other reviews on the distribution, systematics, and conservation status of the Xenarthra of Honduras have been published.

The main objective of this work is to compile the available information on living xenarthrans in Honduras and to discuss the main threats they are facing. We provide published and new localities of anteaters, armadillos, and sloths in the country, and comment on their conservation status.

\section{MATERIALS AND METHODS}

We screened books, articles, dissertations, and theses found in academic research databases (e.g., Google Scholar) as well as technical reports from Honduran government agencies and NGOs for records of xenarthrans. We also queried online databases such as Global Biodiversity Information Facility(GBIF) (https://www.gbif.org), VertNet(http:// www.vertnet.org), Integrated Digitized Biocollections (iDigBio) (https://www.idigbio.org), and iNaturalist (https://www.inaturalist.org) with the terms Bradypus, Cabassous, Choloepus, Cyclopes, Dasypus, Myrmecophaga, and Tamandua, and filtered the results by country to limit them to Honduras. We then verified all coordinates of the obtained records. The following information was extracted for each individual record: species name, locality, municipality and department, year of record, basis of record, and geographic coordinates (when available). We excluded records lacking precise information or scientific evidence for species identification. When the verified coordinates did not match the description, we excluded the record from the map, but did include the written description of its location 
in the text. We also included records registered by us, either by camera trapping (Bushnell, Moultrie, PANTHERA [V3, V4, and V5], Cuddeback, Reconyx, Browning units) or through direct observations, since 2010. Finally, we mapped all records per species; all those found in the literature were marked as "previous", and our unpublished records as "new". We determined the habitat types in which each species was recorded by overlaying the geographical layer of Life Zones (Holdridge, 1987) on the range maps. Detailed information on all obtained records can be found in the SUPPLEMENTARY MATERIAL 1.

Finally, we compiled the local common names of the seven species in Spanish and in different native languages of Honduras. They are given in TABLE 1.

\section{Geographic distribution of the xenarthrans in Honduras}

We found records of seven species of xenarthrans in Honduras, which correspond to those found in Nicaragua (Genoways \& Timm, 2003). To our knowledge, this is the first use of "citizen scientist" observations of xenarthrans from Honduras to map their distribution. Databases such as
iNaturalist hold a great potential for such analyses, provided the location data and identification are accurate.

Bradypus variegatus (FIG. 2). As mentioned above, Goodwin (1942) did not include this species in the list of mammals of Honduras. A few years later, Goodwin (1946) speculated that the distribution of Bradypus may extend to Patricia River (referring to Río Plátano in Departamento Gracias a Dios).

We confirmed 79 records distributed as follows: 21 new records presented herein, one from GBIF (2020), one from iNaturalist (2020), and 32 previous records by Von Hagen (1940), Marineros \& Martínez (1998), McCarthy et al. (1999), Medina-Fitoria (2008), Castañeda et al. (2013b), Mérida Colindres \& Cruz (2014), Marineros \& Portillo Reyes (2015) (see SUPPLementary MATERIAL 1 for a discussion of the origin of some of these records), and La Prensa (2018). In addition, there are 24 zoo specimens listed by Acosta (2016) of which we could not determine if they still are in captivity. We excluded two records from Islas de la Bahía in northern Honduras listed in iNaturalist (2020) because the origin of the individuals is unknown.

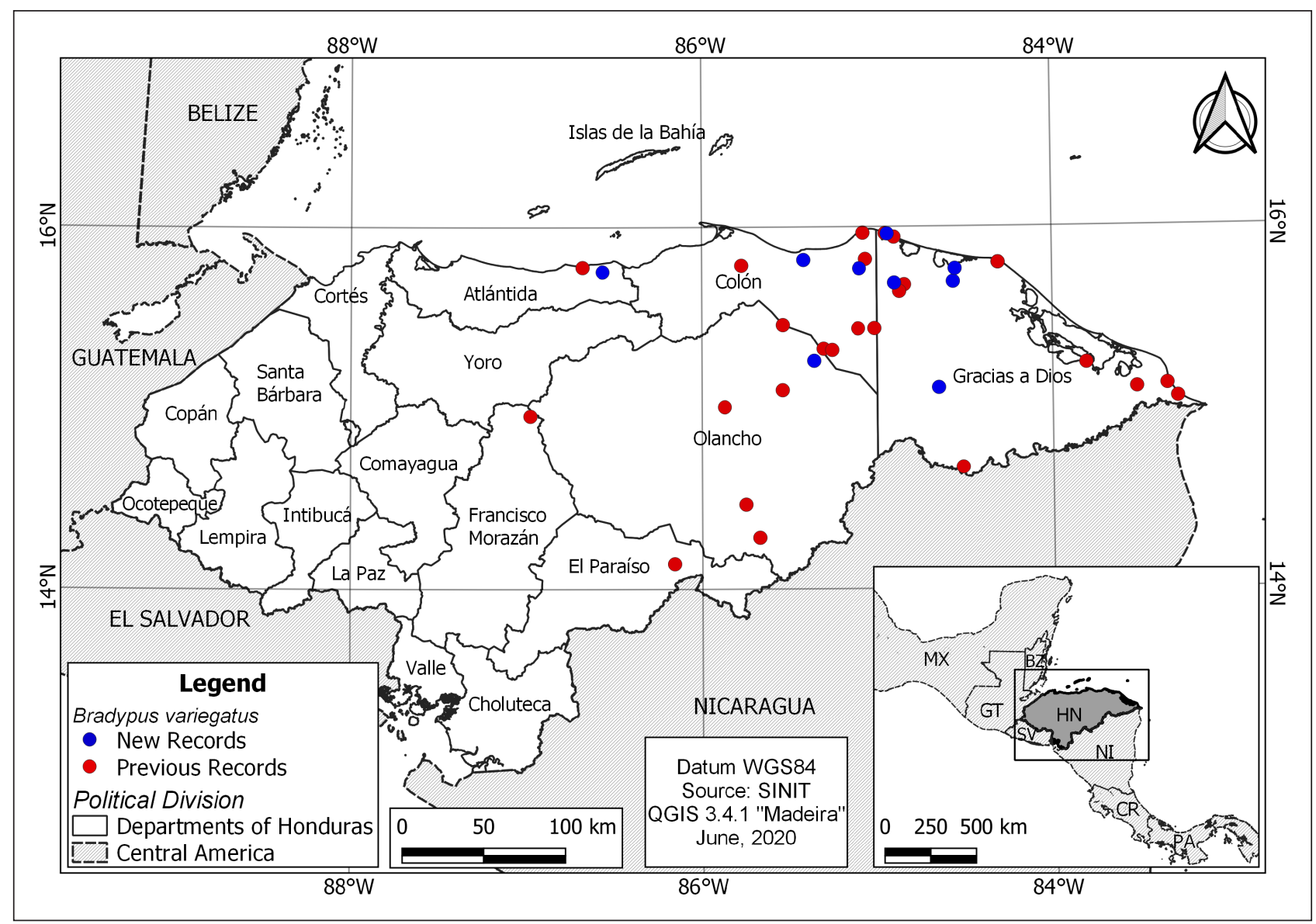

FIGURE 2. Previous and new records of Bradypus variegatus in Honduras. 


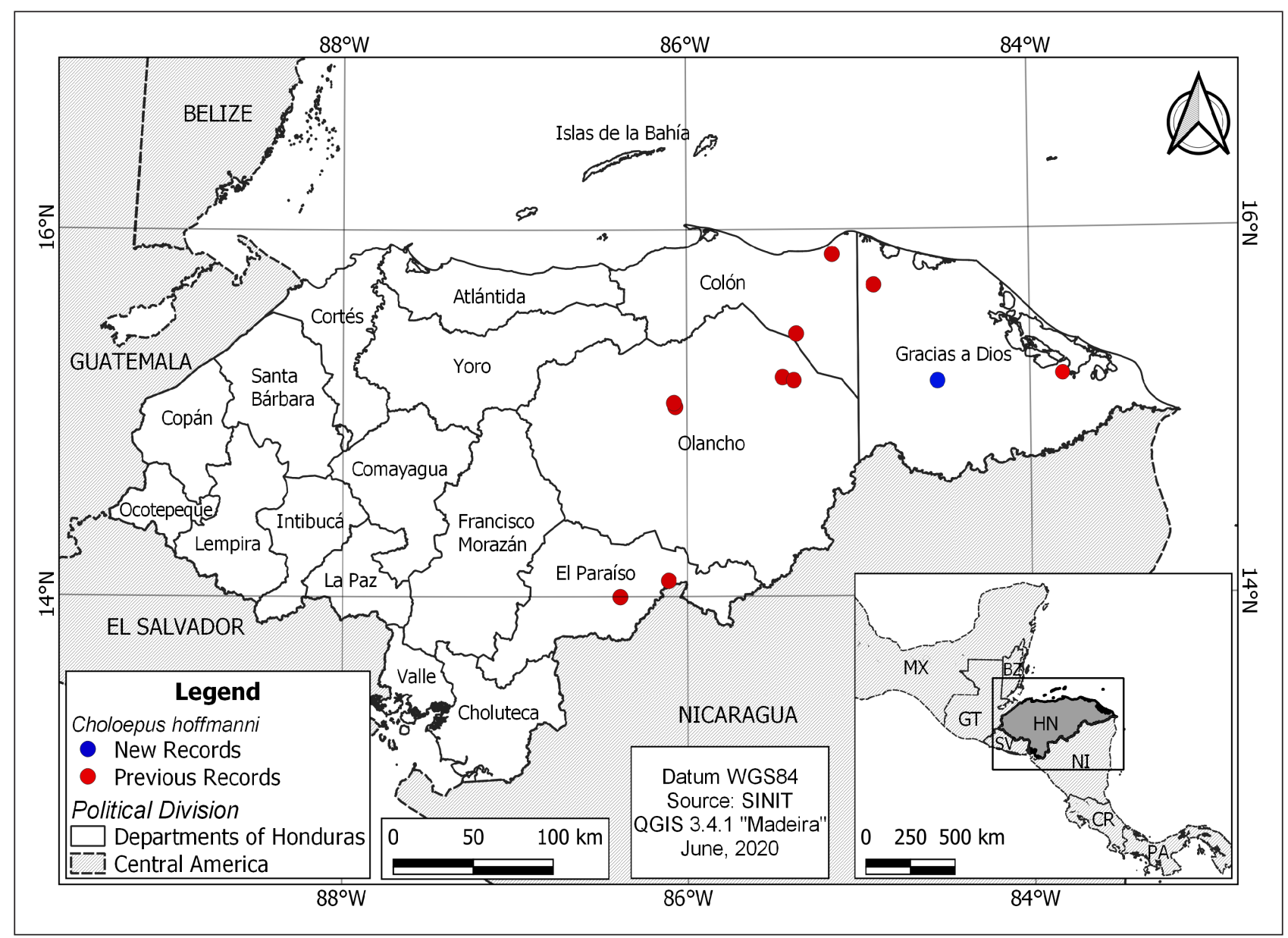

FIGURE 3. Previous and new records of Choloepus hoffmanni in Honduras.

McCarthy et al. (1999) reported specimens in the National Museum of Natural History (USNM) collection and located two B. variegatus skins with skulls (USNM 21010, male; 21011, female) that had been obtained by Perry on 1 June and 9 November 1891, respectively, in Patuca, Honduras. This locality may refer to the coastal settlement of Patuca $\left(15^{\circ} 50^{\prime} \mathrm{N}, 84^{\circ} 17^{\prime} \mathrm{W}\right)$ or Barra Patuca at Punta Patuca

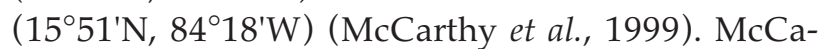
rthy et al. (1999) also mentioned two photographs taken by Von Hagen (1940) of a harpy eagle (Harpia harpyja) attacking a B. variegatus in Montaña de la Flor, in central Honduras. The exact location of this observation is uncertain, as McCarthy et al. (1999) thought it occurred in Francisco Morazán, whereas Marineros \& Portillo Reyes (2015) considered it in Yoro (see FIG. 1). We included this record as part of Francisco Morazán and not Yoro because the record occurred in the drainage of the Guarabuqui River in Orica, which is located in the western region of Francisco Morazán (see McCarthy et al., 1999).

Confirmed records are concentrated in the eastern half of Honduras, in Atlántida, Colón, El Paraíso, Francisco Morazán (where it is thought to be extinct), Gracias a Dios, and Olancho.
Although sloths can be difficult to observe in most areas of the country, B. variegatus may be locally abundant, at least in Honduras. On 18 September 2008, one of us (FC) counted 11 B. variegatus along the canals between Benk and Capri near the village of Raya in eastern Honduras. These records have been cited by Marineros \& Portillo Reyes (2015) with an erroneous location, Raista (see SUPPLEMENTARY MATERIAL 1), and omitting the original authorship. All sloths were resting on mangrove trees at a distance of 1-6 $\mathrm{m}$ from the canal. The observations were made from a moving boat along a $5.5 \mathrm{~km}$ transect in only 36 minutes.

The species may also occur in the tropical forests of Cortés and Yoro, but this needs to be confirmed. Bradypus variegatus has been found in subtropical wet forests and tropical moist forests, including mangroves, at elevations ranging from sea level to $658 \mathrm{~m}$ asl. Based on the frequency of records and the localities, $B$. variegatus seems to be the most common sloth species in Honduras.

Choloepus hoffmanni (FIG. 3). Hoffmann's twotoed sloth is only known from 18 records. The first specimens were mentioned by Gamero (1978) and McCarthy et al. (1999). Martínez et al. (2020b) 
described 13 records obtained between 2012 and 2020, including those mentioned by Acosta (2016). Here we add one additional record in Wampusirpi, Gracias a Dios, in the buffer zone of Río Plátano Biosphere Reserve (RPBR).

The species presence has thus only been confirmed in eastern Honduras, in Colón, El Paraíso, Gracias a Dios, and Olancho. It is probable that it also occurs in Yoro. Choloepus hoffmanni has been recorded in subtropical wet forests and tropical moist forests, at elevations from 53 to 1,000 m asl.

Cyclopes dorsalis (FIG. 4). Only 18 localities of Cy. dorsalis have been recorded since 1891, with one of them (McCain, 2001) consisting of at least two individuals (see below). Eight of them are mentioned by Goodwin (1942), Marineros \& Martínez (1998), McCain (2001), Zepeda et al. (2012), and Bedrossian (2017); nine are from GBIF (2020); and one from iNaturalist (2020). One additional record of unknown origin is listed in GBIF (2020). It is noteworthy that McCain (2001) documented several occurrences of this species in the RPBR, including a mother with her half-grown offspring, but she did not specify the exact number of individuals observed.
The species has been found in Atlántida, Colón, Cortés, El Paraíso, Gracias a Dios, Olancho, Santa Bárbara, and Yoro. It occurs in subtropical wet forests and tropical moist forests, at altitudes between 58 and 1,430 $\mathrm{m}$ asl. Based on the known distribution, it may also occur in northern Comayagua.

Myrmecophaga tridactyla (FIG. 5). The case of M. tridactyla is interesting because, even though Goodwin (1942) included the species for Honduras, he stated that "the great anteater has apparently not been recorded from Honduras. Although rare where it is known to occur in Central America, its range may possibly include suitable localities in Honduras" (Goodwin, 1942:149-150). Today, the giant anteater is considered the most threatened xenarthran in Honduras. It is known from 25 records published by McCain (2001), Marineros \& Martínez (1998), Portillo et al. (2010), Herrera et al. (2011), Gonthier \& Castañeda (2013), Mérida Colindres \& Cruz Días (2014), and Martínez et al. (2020a). Records are from Atlántida, where it is possibly extirpated; Colón, Gracias a Dios, and Olancho. It is restricted to subtropical moist and wet forests and tropical moist forests, where it occurs at elevations from 3 to $598 \mathrm{~m}$ asl. We did not find evidence that the species may be present in other regions of Honduras.

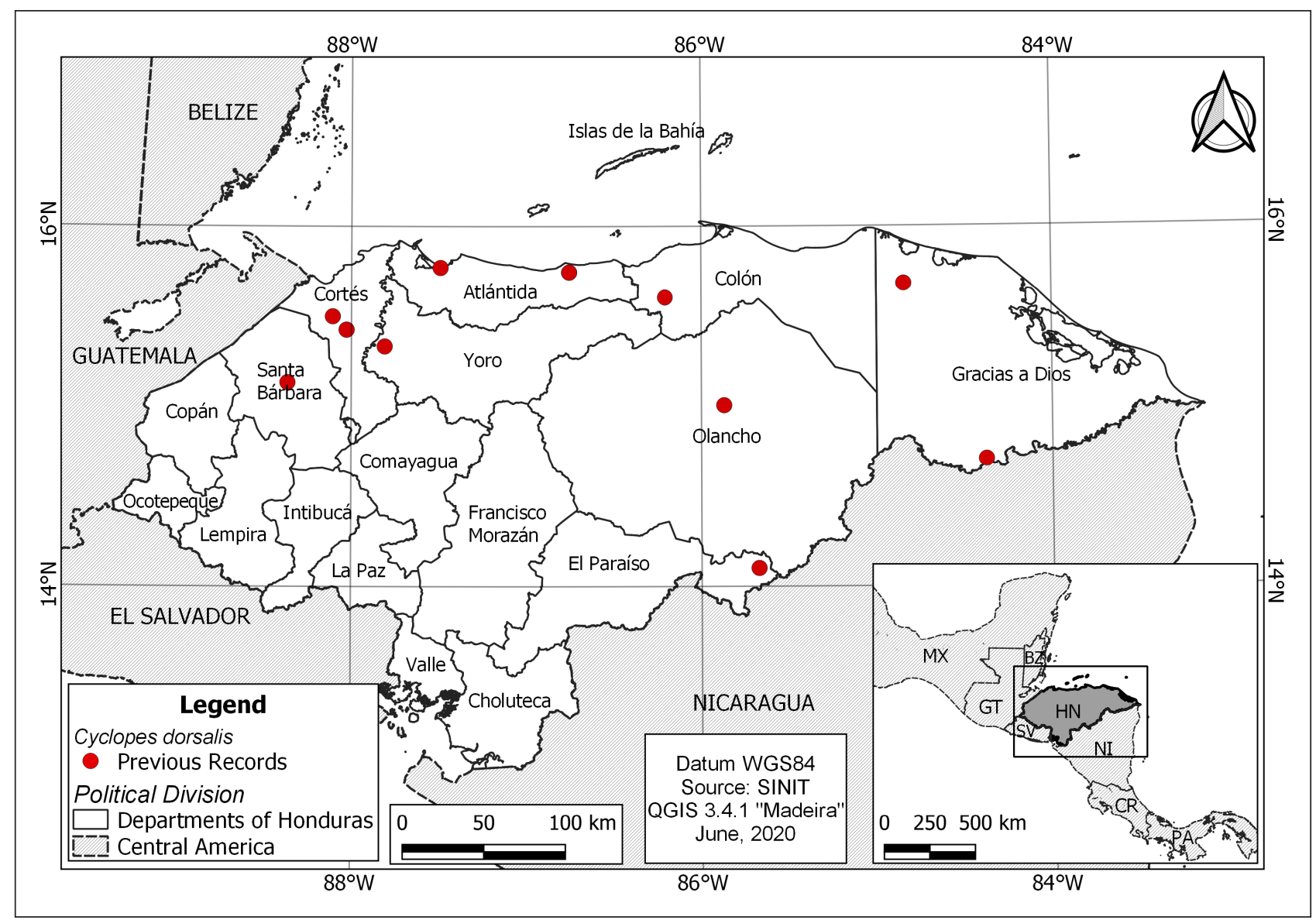

FIGURE 4. Previous records of Cyclopes dorsalis in Honduras. There are no new records reported. 


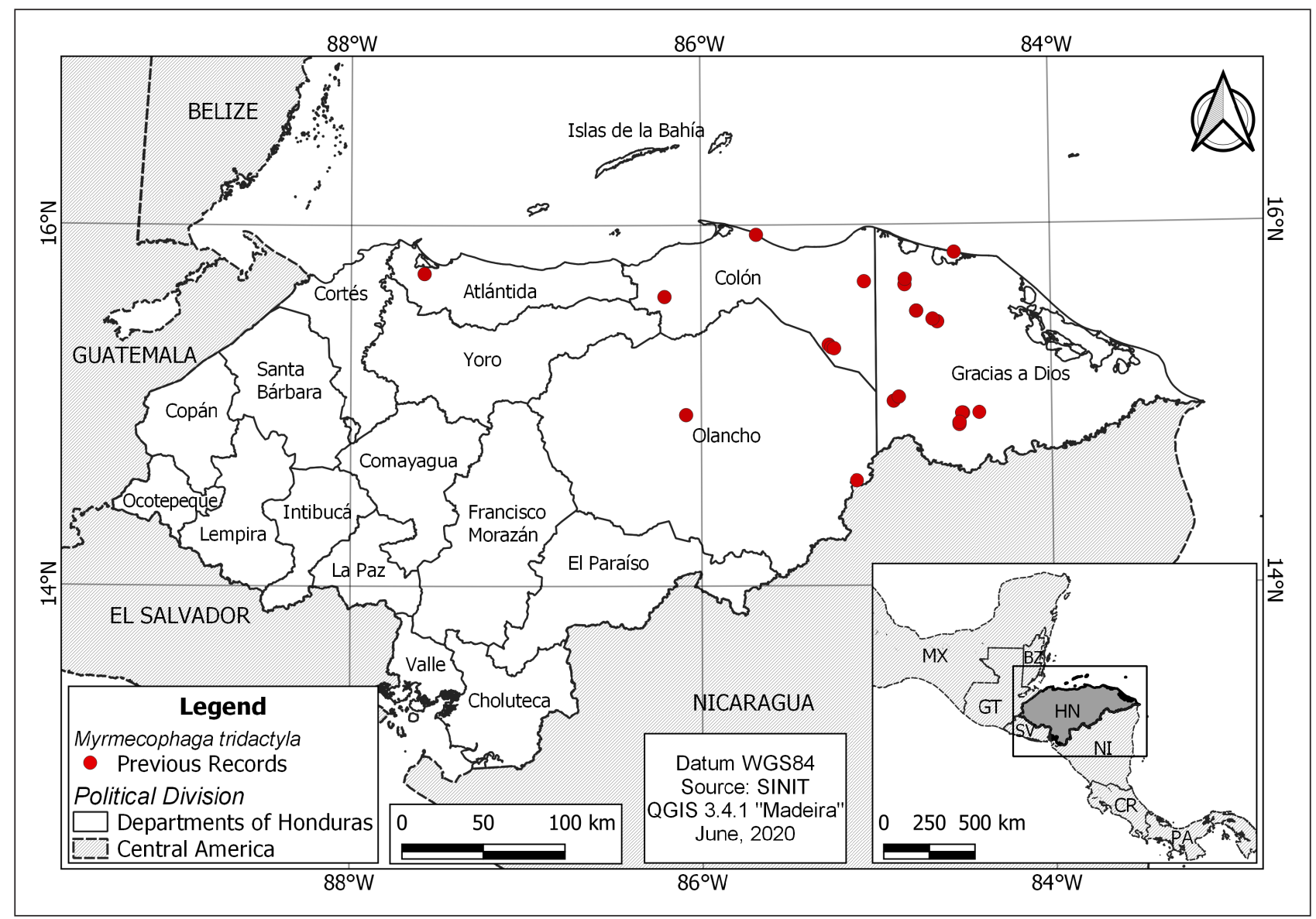

FIGURE 5. Previous records of Myrmecophaga tridactyla in Honduras. There are no new records reported for M. tridactyla.

Tamandua mexicana (FIG. 6). We compiled a total of 105 records of this species in Honduras. There are 47 records published by Benshoof et al. (1984), Marineros \& Martínez (1998), McCain (2001), Komar et al. (2006), CATIE (2007), Medina-Fitoria (2008), Castañeda (2010), Portillo-Reyes \& Hernández (2011), Portillo \& Carrasco (2011), Castañeda et al. (2013a), Hoskins et al. (2018), Portillo et al. (2018), Portillo Reyes (2018), and King et al. (2019). Eight records are listed in GBIF (2020) and 12 in iNaturalist (2020). Seven zoo specimens are mentioned by Acosta (2016), but we could not determine if they are still in captivity. It should be noted that GBIF (2020) lists a record of T. tetradactyla from 1937 in "Atacamus". We consider this record to be T. mexicana because T. tetradactyla was a subspecies of the former at that time (Navarrete \& Ortega, 2011). We could not find any locality called Atacamus; it probably refers to Catacamas in Olancho, where T. mexicana has been recorded previously. We also include 31 new species records. This anteater has a wide distribution in Honduras, and records are only lacking from Lempira, Ocotepeque, and Islas de la Bahía. Considering the lack of research in western Honduras, it is possible that T. mexicana occurs in Lempira and Ocotepeque, but simply has remained unrecorded. This species occurs in subtropical moist forests, subtropical wet forests, tropical dry forests, and tropical moist forests, from sea level to $1,845 \mathrm{~m}$ asl.

Cabassous centralis (FIG. 7). A total of 23 records exist for Honduras. There is one record in GBIF (2020), two in iNaturalist (2020), and 12 published records by Miller (1899), Marineros \& Martínez (1998), Komar et al. (2006), Castañeda et al. (2013b), Portillo Reyes \& Elvir (2013), Hoskins et al. (2018), and MiAmbiente \& Panthera (2018). We did not consider the record of Flores et al. (2019) in Choluteca because their work was based on interviews with local people, and no other evidence supports the species occurrence in southern Honduras. We add eight new records, including the first one in Comayagua. Cabassous centralis is only known from Atlántida, Cortés, Comayagua, Copán, Francisco Morazán, Olancho, and Yoro, at altitudes from 14 to $1,868 \mathrm{~m}$ asl. The species has been recorded in lower montane wet forests, tropical dry forests, subtropical moist forests, tropical moist forests, and subtropical wet forests.

Dasypus novemcinctus (FIG. 8). This is the most widely distributed xenarthran in Honduras. We confirmed 162 records from 1887 to 2020 . Eight of the 29 records in GBIF (2020) and iNaturalist (2020) 
are from unknown locations in eastern Honduras. Ninety-three records are available in the literature by Goodwin (1942), Cruz et al. (1993), Marineros \& Martínez (1998), McCain (2001), Komar et al. (2006), Portillo (2006), Portillo et al. (2006), Medina-Fitoria (2008), Portillo Reyes \& Vásquez (2009), Portillo Reyes \& Hernández (2011), Portillo \& Carrasco (2011), Castañeda et al. (2013a, b), Gonthier \& Castañeda (2013), ASESORA (2009), Portillo Reyes \& Elvir (2013), Mora et al. (2014), Portillo Reyes et al. (2016a,b), Encalada Caicedo (2018), Flores et al. (2018), Hoskins et al. (2018), MiAmbiente \& Panthera (2018), Portillo Reyes (2018), Portillo Reyes \& Elvir (2018), Portillo et al. (2018), and King et al. (2019). We excluded a recent record of D. novemcinctus from Islas de la Bahía, as this individual was probably illegally brought to the island to be kept as a pet. There is no evidence that any xenarthran naturally occurs on these islands. We list 40 new records distributed across the country, including the first official evidence in Ocotepeque. Dasypus novemcinctus is the only xenarthran that has been found in all departments of Honduras, except Islas de la Bahía. It occurs in lower montane moist and wet forests; subtropical dry, moist, and wet forests; and tropical moist forests, at elevations between 28 and $2,133 \mathrm{~m}$ asl.

\section{Main threats to xenarthrans in Honduras}

Several threats are affecting the xenarthrans in Honduras:

Cultural belief. The popular Honduran folk song "El pitero" tells the story of a man trying to catch an armadillo. The theme of this song suggests that, in the past, armadillo consumption was part of the Honduran culture. The song says al indio le gusta el maíz amarillo pero más le gusta el pitero tordillo ('the Indios like yellow corn, but they like the dapple-gray armadillo even more'). Pitero is one of the common names of D. novemcinctus (TABLE 1), but the dapple-gray coloration may rather point towards C. centralis. Finally, the song concludes with tamal de piteros no lo como yo, porque mi abuelita de eso se murió ('I don't eat armadillo tamales because that's what killed my grandmother'). This last verse may be the basis for the popular belief that armadillos, and specifically $C$. centralis, are venomous. Due to this belief, armadillos are killed indiscriminately in some regions of Honduras.

Intentional fires. According to the IUCN Red List of Threatened Species, three xenarthrans, M. tridactyla and both Tamandua species, are threatened by fires (IUCN, 2020; Superina \& Abba, 2020). There is no doubt that forest fires would also directly affect

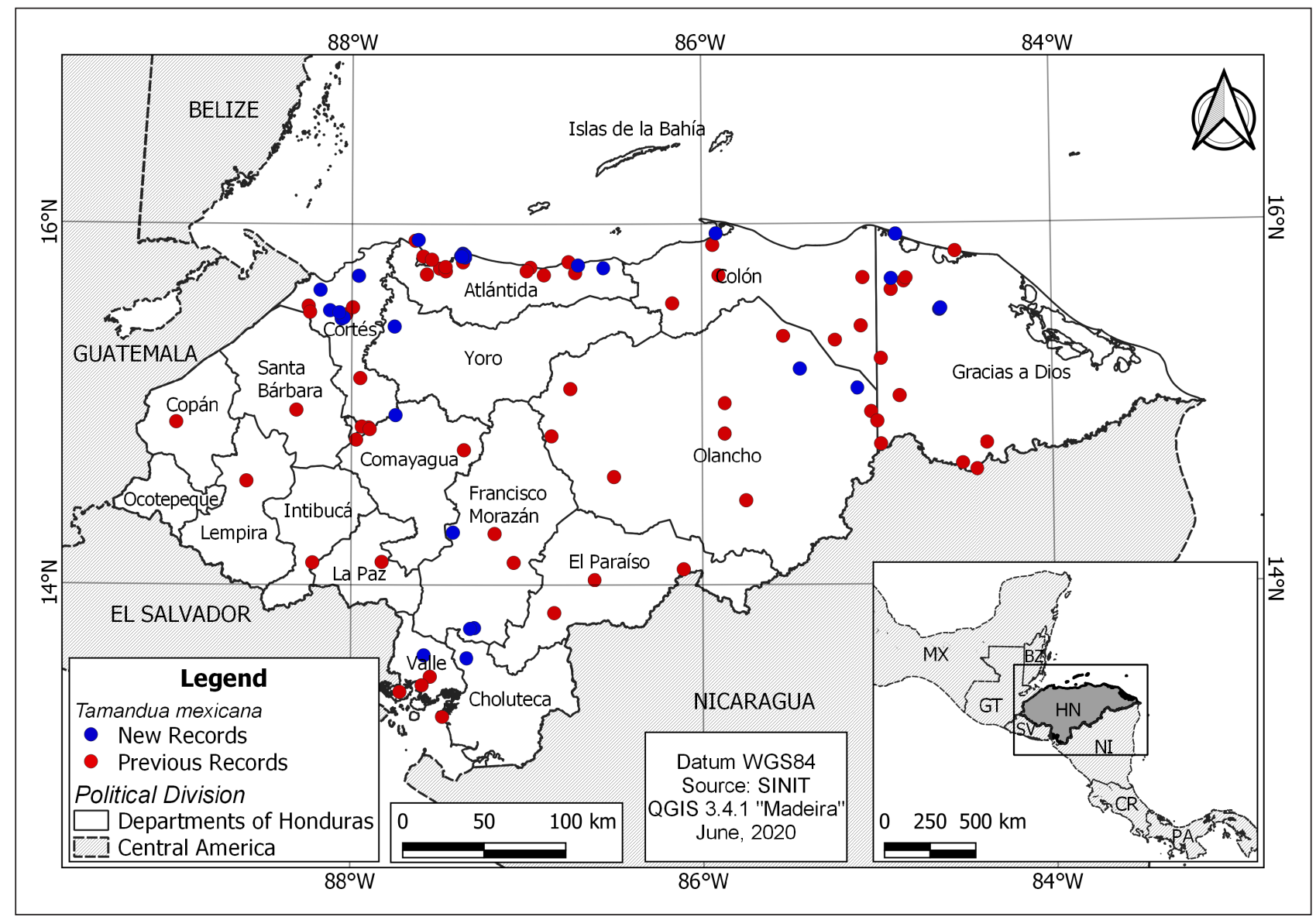

FIGURE 6. Previous and new records of Tamandua mexicana in Honduras. 


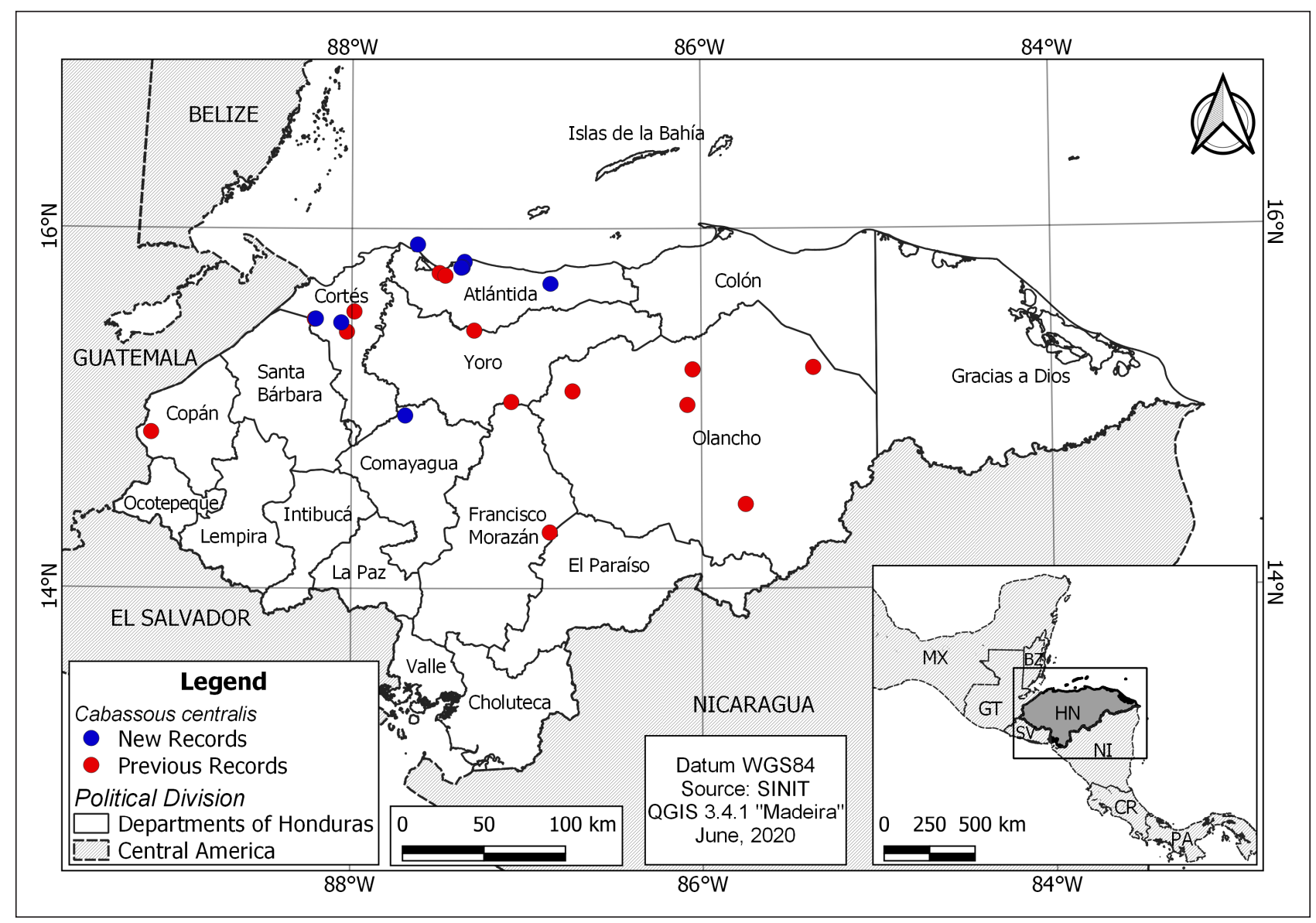

FIGURE 7. Previous and new records of Cabassous centralis in Honduras.

sloths and silky anteaters due to their limited ability to escape, and indirectly through the loss of suitable habitat. In this sense, wildfires are an increasingly important threat to xenarthrans in Honduras, although their impact has not been quantified. In the last decade, Honduras has lost 564,000 hectares of forest due to fires. An estimated $64 \%$ of wildfires are intentionally set, especially in the eastern part of the country, a region known as Honduran Mosquitia that encompasses Colón, Olancho, and Gracias a Dios. In this area, fire is used to clean pine forests (Medina-Moncada, 2018). Six of the seven xenarthrans have been recorded in this area, and it is reasonable to assume that a considerable number of individuals have succumbed during fires. In addition, poachers set fire to warrens, burrows, and caves, and kill the animals that emerge while trying to escape the fire or smoke. We have found burrows that had been set on fire as well as a tamandua hiding in a burned tree (FIG. 9A) in Mico Quemado and Las Guanchías Wildlife Refuge in Yoro. In addition, the most recent outbreak of the pine beetle (Dendroctonus frontalis) occurred between 2014 and 2016 and decimated more than 500,000 hectares of pine forest in 16 of the 18 departments of Honduras (ICF, 2017). Extensive fires have followed across the areas affected by the beetle, most likely reducing populations of D. novemcinctus and T. mexicana, the most common xenarthrans in the pine forest of Honduras.

Habitat loss. Around 1.7 million hectares have been deforested in Honduras during the last 40 years (López, 2015). Deforestation is especially affecting the Honduran Mosquitia. For instance, approximately 58,000 hectares are lost every year in Gracias a Dios (López, 2015). Habitat loss also occurs within the RPBR, which encompasses 832,339 ha (Escuela Nacional de Ciencias Forestales, 2013). Although it is the largest protected area in the country and has one of the most intact forests in Mesoamerica, RPBR is losing 2,700 ha of native vegetation every year (SIGMOF, 2020). This could negatively affect the xenarthrans whose main distribution within the country lies in this area.

Hunting. Agreement 045-2011 allows subsistence hunting in cases of extreme poverty, which must be supported by socioeconomical studies ( $\mathrm{La}$ Gaceta, 2012). Interestingly, of the seven species of xenarthrans occurring in Honduras, only D. novemcinctus is used for subsistence hunting by the ethnic groups of Tawahkas, Miskitus, Pesh, Garífunas, and Mestizos (Portillo, 2007). On the other hand, Article 117 of the Law of Forestry, Protected Areas, and Wildlife, approved by Decree 156-2007, prohibits hunting or capturing threatened and endangered 
species, and stipulates that commercial or sports hunting of non-threatened species may be permitted by the corresponding authorities (Instituto Nacional de Conservación y Desarrollo Forestal, Áreas Protegidas y Vida Silvestre; La Gaceta, 2008). The latter also have the faculty to ban hunting, declare hunting seasons, and regulate the activity. Permits for sports hunting are only issued if updated data on the species distribution, population density, and abundance are available. No authorizations for sports hunting of xenarthrans are currently in place. Illegal hunting does, however, occur. It especially affects armadillos, which are used as trophies, as a protein source, and to manufacture handcrafts (e.g., bags). Armadillos are sold-alive or dead-on roadsides, a phenomenon we have often observed on the southern main road of Honduras. In addition, they are captured, injured, and used as baits to hunt larger-sized animals, especially felids. Poaching occurs both outside and within protected areas, such as Jeannette Kawas National Park and Nombre de Dios National Park. Hunters are usually accompanied by trained dogs that will attack and injure or kill almost any animal they can find, including sloths. Nonetheless, the term perro cusuquero is common in rural areas of Honduras and translates as 'armadillo-dog', referring to dogs that are specially trained to find and hunt armadillos. Poachers with dogs will usually try to avoid M. tridactyla as this large xenarthran can injure or kill dogs. Despite this, poachers will kill giant anteaters precisely due to the threat they represent to their dogs.

Illegal traffic. To our knowledge, no xenarthrans have been exported from Honduras to other countries in the past several years, which suggests that international traffic is currently not a threat. There are no records of any legal export of M. tridactyla, the only Honduran xenarthran listed in the CITES Appendices (T. mexicana is listed in Appendix III only for Guatemala, and Ch. hoffmanni was removed from Appendix III, where it was only listed for Costa Rica, in November 2019; CITES, 2020). McCain (2001) reports on an attempt to illegally export a giant anteater to Asia, but we could not find any other evidence of potential international traffic. There is, however, regional traffic for the pet trade of all xenarthrans, except $M$. tridactyla, that could potentially affect their wild populations. For example, half of the known records of Ch. hoffmanni correspond to confiscated animals or specimens that are located in ex situ conservation centers, which probably have been confiscated from traffickers (Martínez et al., 2020b). It is therefore possible that

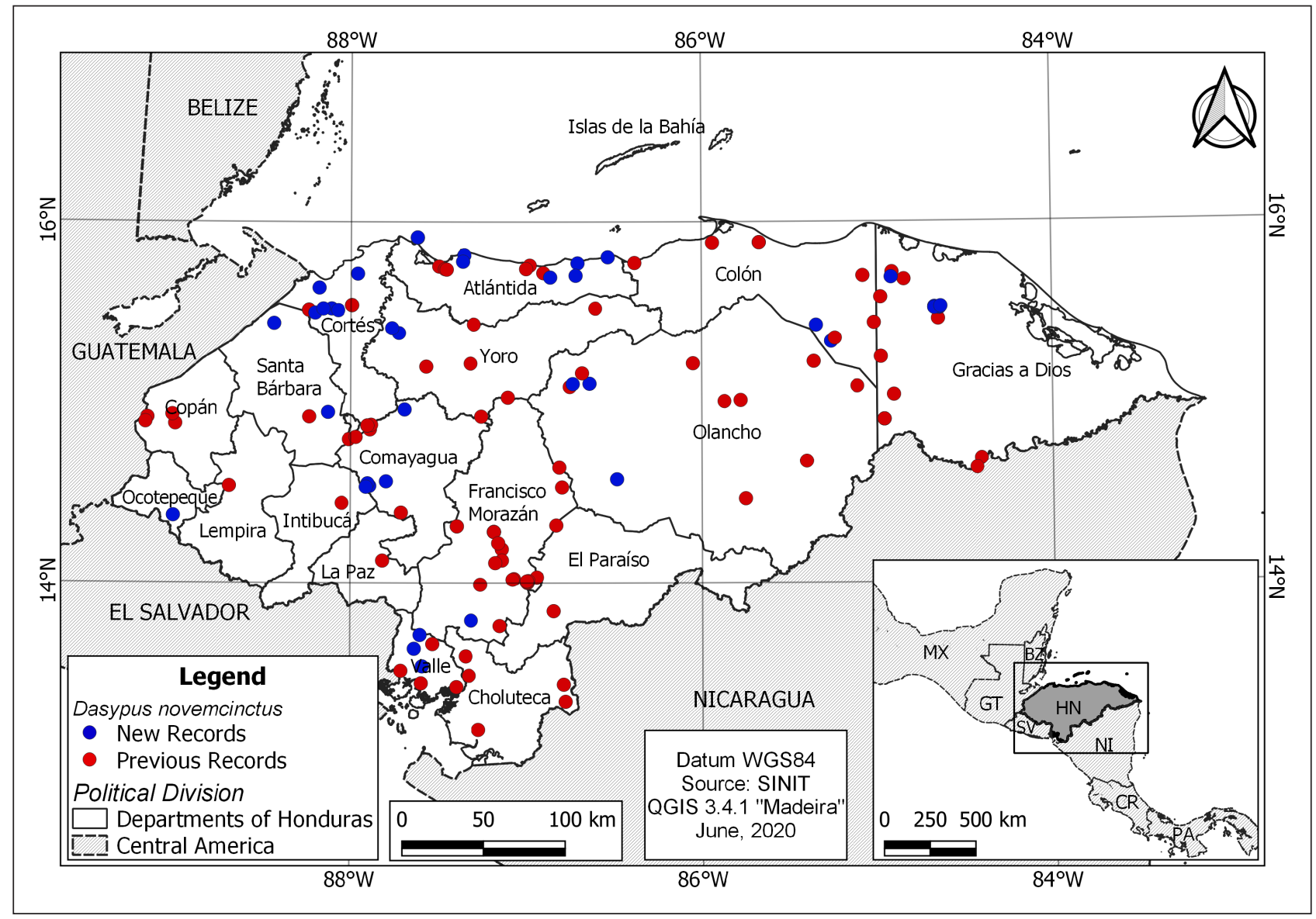

FIGURE 8. Previous and new records of Dasypus novemcinctus in Honduras. 
these activities are affecting the wild sloth populations, and especially those of Ch. hoffmanni, in Honduras. On the other hand, $29 \%$ of the known records of $B$. variegatus correspond to individuals confiscated in 2018 (FIG. 9B), suggesting an increasing pressure on this species. For example, in November of 2018 , ten B. variegatus were found in a cage inside a house in Puerto Lempira, Gracias a Dios. This house was, supposedly, the base for a wildlife trafficking operation in which many different species were held before being shipped outside of La Mosquitia. The sloths were confiscated and returned to their natural habitat, but no arrests or legal actions were taken. Such a large number of seized sloths could have been easily captured by the traffickers at the Raya canals mentioned above, where the species is (or was) abundant. It is difficult to assess the extent of this threat due to the lack of law enforcement and high levels of corruption in most terrestrial, aerial, and marine ports and frontiers, allowing for trafficked animals to pass unnoticed and for law offenders to remain in impunity.

Lack of knowledge, conservation strategies, and awareness. Most armadillo and tamandua records are based on camera trap studies targeted at other species, such as Panthera onca. Research specifically aimed at investigating the ecology, behavior, and natural history of xenarthrans is virtually non-existent in the country. For instance, Cy. dorsalis is a notoriously understudied mammal, and the scarcity of records may be due to the lack of research targeted at this small, inconspicuous species. Especially in southern Honduras, T. mexicana is persecuted due to a lack of awareness. For example, the rescue center "El Ocotal" received three injured tamanduas from Pespire (Choluteca) and La Venta (Francisco Morazán) in three years. One of them had been injured with a machete because it had been "invading" a private property, and the other two had been attacked by locals who thought they were harmful animals. Furthermore, there are no actions taken specifically for the conservation of xenarthrans in Honduras.

Roadkills. Vehicle collisions are an important cause of mortality for many xenarthrans (Superina \& Abba, 2020). This is also true in Honduras, especially on the main roads that cross the country from north to south. New roads are especially problematic, and more so if they border or cross a protected area. Not only do these roads fragment native habitats and increase the chances of wild animals being hit by a vehicle; in addition, people use them to access previously undisturbed forested areas to carry out motocross and other recreative activities that disturb or directly affect wildlife. We have observed T. mexicana roadkills on the new road that connects Copán with Cortés, and found dead tamanduas and armadillos on the road that crosses the
Nombre de Dios National Park to connect Atlántida and Colón. As there are plans to extend this road, we expect an increase in vehicle-induced mortality of xenarthrans, but also other wild species, in the near future.

"Selfie tourism". The use of wildlife as photo props is an increasing cause of concern in terms of animal welfare, especially if it involves direct physical contact between tourists and animals (Carder et al., 2018). Although handling wildlife is illegal in many countries, offering wild animals as photo props is a source of income in many touristic areas (World Animal Protection, 2017). It may also represent a conservation threat, as the animals offered as photo props are often extracted from the wild -which may involve illegal trade-, maintained in inappropriate conditions, and simply replaced by other individuals after their death (Osterberg \& Nekaris, 2015; World Animal Protection, 2017). This is especially true for Bradypus, which are appealing for the wildlife trade and are used as photo props due to their docile nature, but difficult to maintain in captivity (Moreno \& Plese, 2006; Superina et al., 2008; World Animal Protection, 2017; Carder et al., 2018). We have identified "sanctuaries" in northern Honduras that advertised themselves as "ex situ conservation sites", but illegally kept wildlife-including jaguars, capuchin monkeys, and sloths-and charged visitors for taking selfies with the animals. Some animals had been trained using cruel methods, mutilated, or sedated to avoid tourists being harmed during the "selfie time". The fact that sloths are offered as photo props on Islas de la Bahía, where they do not naturally occur, is worrisome, as these animals must have been extracted from the wild in other parts of the country.

\section{Are there any conservation measures in place for the xenarthrans in Honduras?}

In 1998, the environmental authorities (Administración Forestal del Estado-Corporación Hondureña de Desarrollo Forestal, AFE-COHDEFOR) issued Resolution GG-APVS-003-98 to legally protect some species of interest in Honduras. It includes six of the seven Xenarthra species, which is surprising because, as mentioned above, the presence of the two sloth species in Honduras was scientifically documented a year after the resolution (see McCarthy et al., 1999).

Bradypus variegatus and Ch. hoffmanni are listed as rare, with importance for ecotourism, and priority for conservation in certain areas; C. centralis as a species of cultural importance; $M$. tridactyla as endangered, with priority for conservation in certain areas; Cy. didactylus (now Cy. dorsalis) as rare, with importance for ecotourism, trade and consumption, and priority for conservation in certain areas; and T. mexicana as threatened, with importance for 


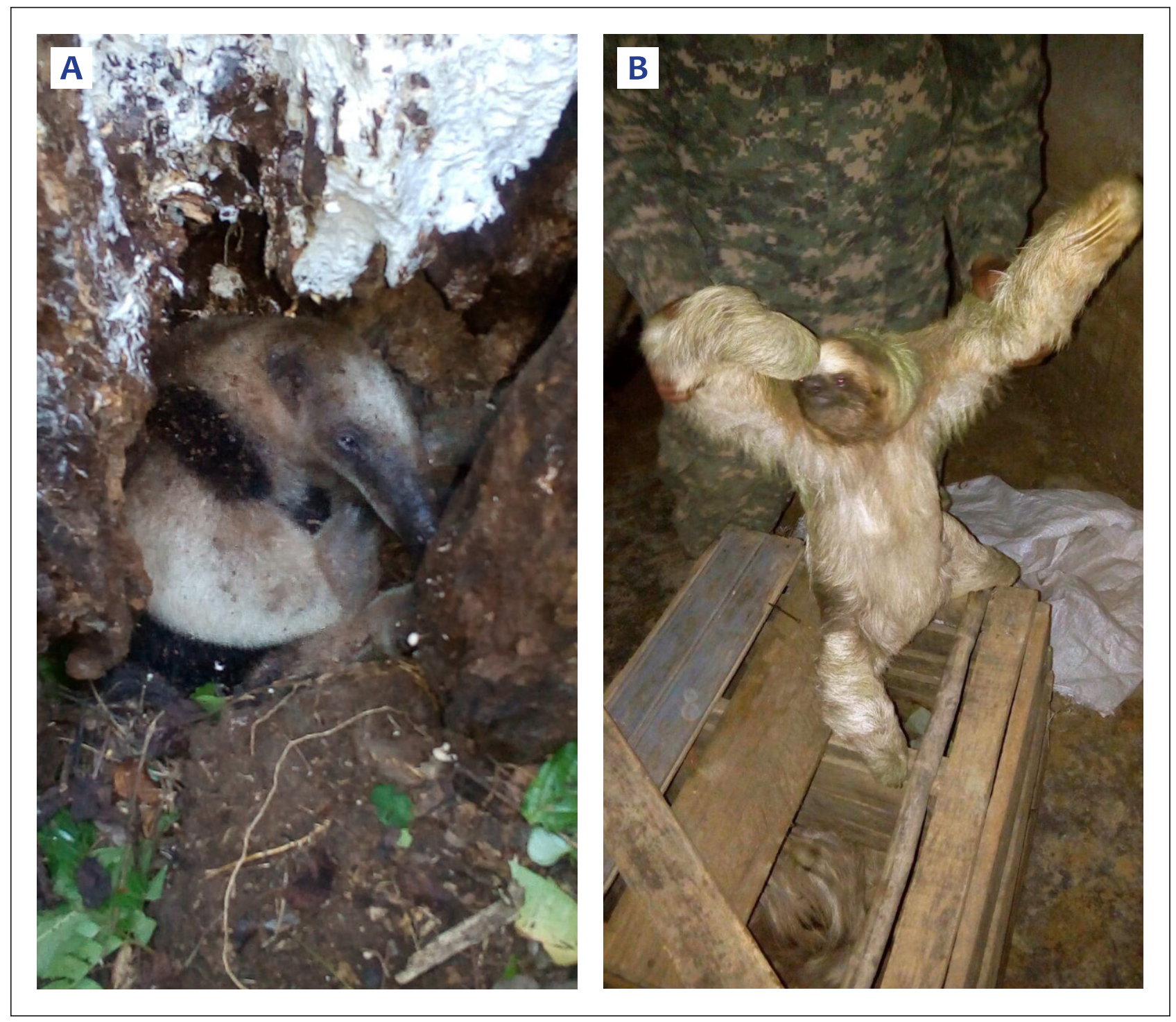

FIGURE 9. A. A Tamandua mexicana sheltered in the hole of a tree that had been set on fire. B. Bradypus variegatus confiscated by military soldiers in Farallones, Colón, in 2018.

ecotourism. It should be noted that species in the category "importance for trade and consumption" may be relevant for either of these two activities, but not necessarily for both of them.

SERNA (2008) published a list of "species of special concern in Honduras", which was meant as an update of Resolution GG-APVS-003-98 but does not replace the latter. None of the xenarthrans was considered by SERNA (2008) to be regionally threatened.

The Law of Forestry, Protected Areas, and Wildlife (Decree 156-2007) stipulates that capturing, hunting or trading wildlife without permission from the corresponding authorities, or mutilating, harming, hitting, causing malnutrition, maltreating, or killing wildlife is a crime against the Honduran fauna that may be sanctioned with 1-9 years of incarceration (La Gaceta, 2008). We are only aware of confiscations of xenarthrans from the illegal trade, but not of any case in which the lawbreaker was sanctioned with incarceration.

Honduras has legal and conservation tools to protect and monitor many species, such as the jaguar (Panthera onca) (ICF, 2011) and the emerald hummingbird (Amazona luciae) (ASESORA, 2009). There are, however, no official documents that specifically mention the importance of, or actions aimed at, the conservation of xenarthrans in Honduras. Hence, their conservation currently depends on the actions of local people and a handful of researchers who have started paying attention to these charismatic species. Xenarthrans do, however, indirectly benefit from action plans for other species, such as jaguars. The latter is considered an umbrella species, and protecting jaguars also helps the conservation of other taxa, including xenarthrans (Figel et al., 2018). 


\section{Conservation status}

The seven xenarthran species that occur in Honduras remain poorly studied, and determining their conservation status at the national level is therefore difficult. At first sight, the range maps (FIGs. 2-8) would suggest that all species have a relatively wide distribution within the country, but they mask the fact that records of some species, such as C. centralis, Cy. dorsalis, and M. tridactyla, are so scarce that even their exact distribution is unclear. Two species, D. novemcinctus and T. mexicana, are present in most of the country and relatively abundant (FIGS. 6, 8). It would thus be reasonable to assume that they should be listed as Least Concern. Any attempt to determine the conservation status of the other species would be educated guesswork at best until additional field data are available. Even though the xenarthrans are protected by law against illegal traffic and poaching, they are hunted and traded in several areas of the country, including in protected areas. Cultural traditions and beliefs, road collisions, deforestation, and selfie tourism could also be negatively affecting the xenarthrans, but the impact of these threats on the wild populations is difficult to assess due to the lack of research.

\section{CONCLUSION}

There is no doubt that we have a lot of work ahead of us to be able to understand and protect the xenarthrans of Honduras. We hope this review helps the research community to know how and where to start, and that it will encourage researchers to initiate ecological and systematic studies about the xenarthrans of Honduras.

\section{ACKNOWLEDGEMENTS}

We thank El Ocotal, especially Alejandro Velásquez, and Danny Ordoñez, for sharing their records. We are grateful to Iris Acosta for her comments on the manuscripts, and to ICF, especially the technicians who are in charge of monitoring the biodiversity in certain areas of Honduras. Finally, we thank two anonymous reviewers, Gabriela F. Ruellan, and Agustín Abba for their comments that helped improve this manuscript. Graduate funding support to TWK was provided by the National Science Foundation Graduate Research Fellowship Program and the US Fulbright Student Fellowship.

\section{REFERENCES}

Acosta, I. 2016. Diagnóstico nacional de centros de conservación ex situ. Departamento de Vida Silvestre, Instituto Nacional de Conservación y Desarrollo Forestal, Áreas Protegidas y Vida Silvestre, Comayagüela, Honduras. 18 pp.

ASESORA. 2009. Plan de manejo del área hábitat/especie del colibrí esmeralda hondureño Amazilia luciae.
Instituto de Conservación y Desarrollo Forestal, Áreas Protegidas y Vida Silvestre/The Nature Conservancy, Honduras. 347 pp.

Bedrossian, P.R. 2017. Osos hormigueros en Centroamérica. https://pablobedrossian.com. Downloaded on 27 May 2020.

Benshoof, L., T.L. Yates \& J.W. Froehlich. 1984. Noteworthy records of mammals from eastern Honduras. The Southwestern Naturalist 29: 511-514. https:// doi.org/10.2307/3671014

Carder, G., et al. 2018. The impact of "selfie" tourism on the behaviour and welfare of brown-throated threetoed sloths. Animals 8: 216. https://doi.org/10.3390/ ani8110216

Castañeda, F. 2010. Potencial de la zona de Manejo Forestal El Venado para realizar un censo de jaguar (Panthera onca): informe gira preliminar, Reserva del Hombre y Biosfera de Río Plátano. Panthera/Ecosistemas/ICF/WCS, Tegucigalpa, Honduras. 15 pp.

Castañeda, F., L. Herrera \& S. Pereira. 2013a. Muestreo preliminar del jaguar (Panthera onca) y sus presas en el Parque Nacional Patuca. Panthera/HelvetasHonduras/Asociación Patuca, Tegucigalpa, Honduras. $12 \mathrm{pp}$.

Castañeda, F., S. Pereira, L. Herrera \& N. Estrada. 2013b. Diversidad de mamíferos terrestres en fincas de cacao de Olancho, Honduras. Panthera/Helvetas-Honduras/APROSACAO, Tegucigalpa, Honduras. 19 pp.

CATIE-Centro Agronómico Tropical de Investigación y Enseñanza. 2007. Línea base de fauna silvestre en la Reserva Biosfera Tawahka Asangni y la parte sur de La Biosfera del Río Plátano. ICADE/TROCAIRE, Honduras. 90 pp.

CITES. 2020. Convention on International Trade in Endangered Species of Wild Fauna and Flora. https:// www.cites.org. Downloaded on 1 July 2020.

Cruz, G.A., V.J. López \& S. Rodríguez. 1993. Primer inventario de mamíferos, reptiles y anfibios del Parque Nacional Celaque. COHDEFOR/ODA/ESNACIFOR, Siguatepeque, Honduras. 33 pp.

Duarte, E. A., et al. 2014. Mapa forestal y de cobertura de la tierra de Honduras: análisis de cifras nacionales. Instituto Nacional de Conservación y Desarrollo Forestal, Áreas Protegidas y Vida Silvestre (ICF)/ Programa Regional REDD/CCAD-GIZ, Honduras. $24 \mathrm{pp}$.

Encalada Caicedo, L.M. 2018. Patrones de actividad diaria de mamíferos medianos y grandes de la Reserva Biológica Uyuca mediante fototrampeo. Escuela Agrícola Panamericana, Zamorano, Honduras. 26 pp.

Escuela Nacional de Ciencias Forestales. 2013. Plan de Manejo Reserva del Hombre y la Biosfera Río Plátano (2013-2025). Asociación Internacional de Fomento (AIF) e Instituto Nacional de Conservación y Desarrollo Forestal, Áreas Protegidas y Vida Silvestre (ICF), Comayagüela, M.D.C. 252 pp.

Ferreira, D.J. \& M.I. Feijó Ramos. 2011. Análise bioestratinômica de Eremotherium laurillardi (Lund, 1842) de 
depósitos pleistocênicos, município de Itaituba, Pará. Brazilian Geographical Journal: Geosciences and Humanities Research Medium 2: 121-131.

Figel, J.J., F. Castañeda, A.P. Calderón, J.A. de la Torre, E. García-Padilla \& R.F. Noss. 2018. Threatened amphibians sheltered under the big cat's umbrella: conservation of jaguars Panthera onca (Carnivora: Felidae) and endemic herpetofauna in Central America. Revista de Biología Tropical 66: 1741-1753. https://doi.org/10.15517/RBT.V66I4.32544

Flores, A., R. Ortíz, S. Pacheco, V. Cabrera, L. Gutiérrez \& N. Estrada. 2019. Uso de fauna y flora silvestre en la comunidad de Duyusupo y El Jocote, Choluteca, Honduras. Revista Portal de la Ciencia 16: 78-95. https://doi.org/10.5377/pc.v0i16.8097

Gamero, I. 1978. Mamíferos de mi tierra. Volumen 2. Banco Central de Honduras, Tegucigalpa, Honduras. 234 pp.

GBIF - Global Biodiversity Information Facility. 2020. GBIF occurrence. <http://www.gbif.org>. Downloaded 20 May 2020.

Genoways, H.G. \& R.M. Timm. 2003. The Xenarthra of Nicaragua. Los Xenarthra de Nicaragua. Mastozoología Neotropical 10: 231-253.

Gonthier, D. J. \& F.E. Castañeda. 2013. Large- and medium-sized mammal survey using camera-traps in the Sikre River in the Río Plátano Biosphere Reserve, Honduras. Tropical Conservation Science 6: 584-591. https://doi.org/10.1177/194008291300600409

Goodwin, G.G. 1942. Mammals of Honduras. Bulletin of the American Museum of Natural History 79: 107-195.

Goodwin, G.G. 1946. Mammals of Costa Rica. Bulletin of the American Museum of Natural History 87: 271-474.

Hall, E.R. 1981. The mammals of North America. $2^{\text {nd }}$ ed. John Wiley and Sons, New York, USA. 1,181 pp.

Hernández Oré, M.A., L.D. Sousa \& J.H. López. 2016. Honduras: desatando el potencial económico para mayores oportunidades. Diagnóstico sistemático de país. Banco Internacional de Reconstrucción y Fomento/Banco Mundial, Washington, USA. 165 pp.

Herrera, L.H., F.E. Castañeda \& S.C. Pereira. 2011. El Jaguar (Panthera onca) en la zona de manejo forestal comunitario El Venado Río Plátano. Panthera, Tegucigalpa, Honduras. 14 pp.

Holdridge, L.R. 1987. Ecología basada en zonas de vida (Jiménez Saa, H. Trad.). Instituto Interamericano de Cooperación para la Agricultura (IICA), San José, Costa Rica. 216 pp.

Hoskins, H.M.J., et al. 2018. Non-volant mammal inventory of Cusuco National Park, north-west Honduras: reporting the presence of jaguar, Panthera onca (Linnaeus, 1758), and demonstrating the effects of zonal protection on mammalian abundance. Check List 14: 877-891. https://doi.org/10.15560/14.5.877

ICF-Instituto Nacional de Conservación y Desarrollo Forestal, Áreas Protegidas y Vida Silvestre. 2011.
Plan nacional para la conservación del jaguar (Panthera onca), Honduras. ICF-Proyecto Ecosistemas/ Panthera, Tegucigalpa, Honduras. 47 pp.

ICF - Instituto Nacional de Conservación y Desarrollo Forestal, Áreas Protegidas y Vida Silvestre. 2017. Informe de episodio de ataque del gorgojo descortezador del pino Dendroctonus frontalis en Honduras 2014-2017. Departamento de Salud y Sanidad Forestal, Instituto Nacional de Conservación y Desarrollo Forestal, Áreas Protegidas y Vida Silvestre, Honduras. 69 pp.

iNaturalist. 2020. iNaturalist research-grade observations. Occurrence dataset. <https://www.inaturalist.org>. Downloaded on 12 July 2020.

INE - Instituto Nacional de Estadística. 2018. Indicadores cifras de país 2018. Available at: https://www.ine. gob.hn/V3/imag-doc/2019/09/cifras-de-pais-2018.pdf

IUCN - International Union for the Conservation of Nature. 2020. The IUCN Red List of Threatened Species. Version 2020-1. https://www.iucnredlist.org. Downloaded on 1 May 2020.

Jackson, D.R. \& E. Fernandez. 2005. A small Pleistocene mammalian megafauna from southern Honduras. Bulletin of the Florida Museum of Natural History 45: 261-269.

Jones, J.K., Jr. 1965. Some Miskito Indian names for mammals. Journal of Mammalogy 46: 353-354. https:// doi.org/10.2307/1377878

King, T., J. Polisar \& M.A. Turcios-Casco. 2019. Medium and large-sized mammals of Ciudad Blanca, La Mosquitia, Honduras. Pp. 204-216 in: Evaluación biológica rápida en Ciudad del Jaguar, Ciudad Blanca, La Mosquitia, Honduras (T.H. Larsen, ed.). Conservation International, Arlington, Virginia, USA.

Komar, O., et al. 2006. Evaluación de la biodiversidad del Parque Arqueológico y Reserva Forestal Río Amarillo (Copán, Honduras). Informe de consultoría para el Banco Interamericano de Desarrollo. SalvaNATURA/NatureServe, Washington, D.C., USA. 44 pp.

La Gaceta. 2008. Decreto No. 156-2007. Ley forestal, áreas protegidas y vida silvestre. Available at: https:// www.tsc.gob.hn/biblioteca/index.php/leyes/118ley-general-de-areas-protegidas-y-vida-silvestre

La Gaceta. 2012. Acuerdo número 045-2011. Manual de normas técnico-administrativas para el manejo y aprovechamiento sostenible de la vida silvestre de Honduras. Available at: http://www. melarayasociados.com/legislacion/marzo2012/ ACUERDO-No.-045-2011-Aprobar-el-Manual-deNormas-Tecnico-Administrativas-para-el-Manejo$\mathrm{y}$-Aprovechamieto-Sostenible-de-la-Vida-Silvestrede-Honduras.pdf

La Prensa. 2018. Fiscalía de Honduras recupera 10 osos perezosos en La Mosquitia. Available at: https:// www.laprensa.hn/honduras/1235597-410/fiscal $\%$ C3\%ADa-de-honduras-recupera-10-osos-perezosos-en-la-mosquitia

López, E. 2015. La deforestación del bosque en Honduras: entre tala ilegal y una endeble institucionalidad. 
Centro de Estudio para la Democracia (CESPAD), Tegucigalpa. $10 \mathrm{pp}$.

Lucas, S.G. 2008. Pleistocene mammals from Yeroconte, Honduras. Bulletin - New Mexico Museum of Natural History and Science 44: 403-407.

Marineros, L. \& F. Martínez. 1998. Guía de campo de los mamíferos de Honduras. Instituto Nacional de Ambiente y Desarrollo (INADES), Tegucigalpa, Honduras. $374 \mathrm{pp}$.

Marineros, L. \& H.O. Portillo Reyes. 2015. Actualización de la distribución y notas sobre el perezoso de tres garras Bradypus variegatus castaneiceps (Pilosa: Bradypodidae) en Honduras. Revista Mexicana de Mastozoología (Nueva Época) 5: 1-14. http://doi. org/10.22201/ie.20074484e.2015.5.1.202

Martínez, M.A., M.A. Turcios-Casco \& S.P. Amador. 2020a. On the conservation of Myrmecophaga tridactyla (Pilosa: Myrmecophagidae) in the core of Río Plátano Biosphere Reserve, Honduras. Mammalia. http://dx.doi.org/10.1515/mammalia-2019-0152

Martínez, M., A. Velásquez, M.A. Turcios-Casco, S. Pacheco, N. Cabrera \& I. Acosta. 2020b. El perezoso de dos dedos en Honduras: distribución, historia natural y conservación. Notas sobre Mamíferos Sudamericanos (September issue): 1-9. http://doi.org/ 10.31687/saremNMS.20.0.25

McCain, C.M. 2001. First evidence of the giant anteater (Myrmecophaga tridactyla) in Honduras. The Southwestern Naturalist 46: 252-254. https://doi.org/ $10.2307 / 3672542$

McCarthy, T.J., D. Anderson \& G.A. Cruz. 1999. Tree sloths (Mammalia: Xenarthra). Nicaragua and Honduras, Central America. The Southwestern Naturalist 44: $410-414$.

Medina-Fitoria, A. 2008. Evaluación mastozoológica en la Reserva de Biosfera Río Plátano en el noreste de Honduras. MOPAWI/SERNA (Proyecto Corazón), Tegucigalpa, Honduras. 21 pp.

Medina-Moncada, L. B. 2018. Estrategia nacional de uso y manejo de fuego 2018-2028 con su plan de acción. Programa de Adaptación al Cambio Climático en el Sector Forestal-CLIFOR, Tegucigalpa, Honduras. 63 pp.

Mérida Colindres, J.E. \& G. A. Cruz. 2014. Mamíferos del Parque Nacional Nombre de Dios, costa caribeña de Honduras, con nuevos registros para el Departamento de Atlántida. Cuadernos de Investigación UNED 6: 233-237. https://doi.org/10.22458/urj. v6i2.629

Mérida Colindres, J.E. \& G.A. Cruz Días. 2014. Confirmación de la presencia del oso hormiguero gigante Myrmecophaga tridactyla centralis (Xenarthra: Myrmecophagidae) en la Reserva Biósfera Río Plátano, Departamento de Gracias a Dios, Honduras, con descripción y comentarios sobre su estatus taxonómico. Edentata 15: 9-15. https://doi. org/10.5537/020.015.0112

MiAmbiente \& Panthera. 2018. Estatus del jaguar (Panthera onca) y sus presas en el Refugio de Vida Silves- tre Texiguat y los Parques Nacionales de Pico Pijol y Montaña de Yoro. MiAmbiente-Panthera, Tegucigalpa, Honduras. 137 pp.

Miller, G.S., Jr. 1899. Notes on the naked-tailed armadillos. Proceedings of the Biological Society of Washington 13: 1-8.

Miranda, F.R., D.M. Casali, F.A. Perini, F.A. Machado \& F. R. Santos. 2018. Taxonomic review of the genus Cyclopes Gray, 1821 (Xenarthra: Pilosa), with the revalidation and description of new species. Zoological Journal of the Linnean Society 20: 1-35. https://doi. org/10.1093/zoolinnean/zlx079

Mora, J.M., L.I. López, M. Acosta \& P. Maradiaga. 2014. Plan de manejo Reserva Biológica Uyuca 2013-2025. Instituto Nacional de Conservación y Desarrollo Forestal, Áreas Protegidas y Vida Silvestre/Escuela Agrícola Panamericana, Honduras. 165 pp.

Moreno, S. \& T. Plese. 2006. The illegal traffic in sloths and threats to their survival in Colombia. Edentata 7: 10-18. https://doi.org/10.1896/1413-4411.7.1.10

Navarrete, D. \& J. Ortega. 2011. Tamandua mexicana (Pilosa: Myrmecophagidae). Mammalian Species 43 (874): 56-63. https://doi.org/10.1644/874.1

Osterberg, P. \& K. A.I. Nekaris. 2015. The use of animals as photo props to attract tourists in Thailand: a case study of the Slow Loris Nycticebus spp. TRAFFIC Bulletin 27: 13-18.

Portillo, H. 2006. Establecimiento de una línea base para la evaluación de los mamíferos terrestres del Parque Nacional La Tigra usando trampas cámaras. GIBBALAM, Tegucigalpa, Honduras. 31 pp.

Portillo, H. O. 2007. Recopilación de la información sobre la biodiversidad de Honduras. INBIO-DiBio. Tegucigalpa, Honduras. 234 pp.

Portillo, H. \& J.C. Carrasco. 2011. Monitoreo biológico usando trampas cámara en el sendero de las Bujajas, Refugio de Vida Silvestre de Cuero y Salado. Evaluando el efecto de la visitación turística. Proyecto Turismo Sostenible en Honduras Fase II, La Ceiba, Honduras. 25 pp.

Portillo, H.O., F. Elvir \& D. Mejía. 2018. Diseño de un sistema de monitoreo biológico terrestre para la Bahía de La Unión y la Bahía de Chismuyo en el Golfo de Fonseca. Agencia de los Estados Unidos para el Desarrollo (USAID)/UICN, Tegucigalpa, Honduras. $62 \mathrm{pp}$.

Portillo, H. O., W.A. Matamoros \& S.L. Glowinski. 2010. Distribution and conservation status of the giant anteater (Myrmecophaga tridactyla) in Honduras. The Southwestern Naturalist 55: 119-121. https://doi. org/10.1894/CLG-25.1

Portillo, H., C. Zelaya \& M. Vásquez. 2006. Ecología de la sub-población de jaguar (Panthera onca) en el Parque Nacional Pico Bonito y el Refugio de Vida Silvestre Texiguat. International Resources Group, Washington, D.C., USA. 38 pp.

Portillo Reyes, H.O. 2018. Monitoreo participativo de biodiversidad en el Corredor Biológico La Unión (estu- 
dio de fauna \& capacitación). DiBio-MiAmbiente/ Agencia de Cooperación Internacional del Japón (JICA), Tegucigalpa, Honduras. 53 pp.

Portillo Reyes, H.O. \& F. Elvir. 2013. Composición, estructura y diversidad de mamíferos terrestres grandes y medianos en 16 áreas protegidas en Honduras, usando fotocapturas como evidencia de registro. Mesoamericana 17: 15-29.

Portillo Reyes, H.O. \& F. Elvir. 2018. Mamíferos en dos bosques riparios de la sabana de pino en La Moskitia hondureña. Revista Mexicana de Mastozoología (Nueva Época) 8: 22-30. https://doi.org/10.22201/ ie.20074484e.2018.1.2.262

Portillo Reyes, H. O. \& J. Hernández. 2011. Densidad del jaguar (Panthera onca) en Honduras: primer estudio con trampas-cámara en La Mosquitia hondureña. Revista Latinoamericana de Conservación 2: 45-50.

Portillo Reyes, H.O. \& M. Vásquez. 2009. Expedición y evaluación de la Reserva de la Biosfera Tawahka, La Mosquitia, Honduras. Wildlife Conservation Society, Tegucigalpa, Honduras. 26 pp.

Portillo Reyes, H.O., F. Elvir, K. Lara \& P. Rico. 2016a. Felinos y sus presas en los senderos turísticos, del Parque Nacional Azul Meámbar (PANACAM), Honduras. Scientia hondurensis 1: 44-57.

Portillo Reyes, H.O., et al. 2016b. Diversidad y riqueza para tres sitios del bosque de pino-encino en el departamento de Olancho, Honduras. Scientia hondurensis 1: 136-156.

SDGEPIAH - Sub-Dirección General de Educación para Pueblos Indígenas y Afro-hondureños. 2015. Diccionario Pesh. Available at: https://www.se.gob.hn/ media/SDGEPIAH/files/PESH_1.pdf

SIGMOF-Sistema de Información para la Gestión y Monitoreo Forestal. 2020. Mapa de cobertura y uso de la tierra. Available at: http://sigmof.icf.gob. $\mathrm{hn} /$ ?page_id $=4590$
SERNA - Secretaría de Recursos Naturales y Ambiente. 2008. Especies de preocupación especial en Honduras. Tegucigalpa, Honduras. $77 \mathrm{pp}$.

Superina, M. \& A.M. Abba. 2020. Conservation perspectives for a highly disparate lineage of mammals: the Xenarthra. Mastozoología Neotropical 27: 48-67. https://doi.org/10.31687/saremMN_SI.20.27.1.06

Superina, M., F. Miranda \& T. Plese. 2008. Maintenance of Xenarthra in captivity. Pp. 232-243 in: The biology of the Xenarthra (S.F. Vizcaíno \& W.J. Loughry, eds.). University Press of Florida, Gainesville.

Turcios-Casco, M.A., et al. 2020. A systematic revision of the bats (Chiroptera) of Honduras: an updated checklist with corroboration of historical specimens and new records. Zoosystematics and Evolution 96: 411-429. https://doi.org/10.3897/zse.96.51059

Von Hagen, V.W. 1940. Jungle in the clouds: a naturalist's explorations in the Republic of Honduras. Duell, Sloan, and Pearce, New York, USA. 268 pp.

World Animal Protection. 2017. Un acercamiento a la crueldad: el impacto nocivo de los selfies con vida silvestre en el Amazonas. Heredia, Costa Rica. 40 pp.

Zepeda, C., J. Andino \& S. Midence. 2012. Acciones del biólogo. SIMBIOSIS - Boletín Oficial del Colegio de Biólogos de Honduras 1: 11-12.

Zúniga, L., L. Enríquez, C. López-Videz \& D. Aguilar. 2019. Recuperación de tejidos blandos de perezosos fósiles gigantes (Mammalia, Xenarthra, Pilosa) de la zona central del Departamento de Yoro, Honduras. Revista Ciencia y Tecnología 24: 32-48. https://doi. org/10.5377/rct.v0i24.7875

Received: 29 June 2020; Accepted: 2 November 2020 